\title{
Wollastonite Ceramic/CuO Nano-Composite for Cadmium Ions Removal from Waste Water
}

\author{
Nabila Ammar ${ }^{1}$, Ahmed Fahmy A. Youssef ${ }^{2}$, S. H. Kenawy ${ }^{3 *}$, E.M.A. Hamzawy ${ }^{4}$, \\ M.A. El-Khateeb ${ }^{1}$ \\ ${ }^{1}$ Water Pollution Control Department, National Research Center, ${ }^{2}$ Chemistry \\ Department, Cairo University, ${ }^{3}$ Ceramic Department, ${ }^{4}$ Glass Department, National \\ Research Center, Dokki, Cairo, Egypt.
}

\begin{abstract}
JANO-PARTICLES, within 29-45 nano-meters, based on wollastonite were prepared with/ 1 without $\mathrm{CuO}$ through wet method. The adsorption process was occurred on nano-particles powder ceramic at different conditions ( $\mathrm{pH}$, contact time and dose) for removing of cadmium ions from waste water. The SEM of nano-particles after treatment of waste water revealed that, surface texture of the blank adsorbents changes totally due to the adsorption of cadmium ions on the particles. At optimum operating conditions (at $\mathrm{pH}$ 9) cadmium ions removal reached $98.88 \%$ after measurement by ICP and EDX techniques. The obtained results showed that the produced ceramic nano-particles could be used efficiently for removal of cadmium ions with reasonable simple and low cost technique.
\end{abstract}

Keywords: Wollastonite, Ceramic, Nano materials, Water treatment, Adsorption.

\section{Introduction}

The heavy metals (HM) release into the environment has a potential threatening effect to water, soil quality as well as to plant, animal and human health, directly and indirectly. Heavy metals adversely affect the fertility of soils, production of plants, animals and the entire environment if exceed certain limits [1]. Furthermore, these metals could be soluble in aquatic media in the environment and consequently, may be easily absorbed by the cells of living creatures. Thus, by entering the food chain, HM could be bioaccumulated in higher levels of food chain. When HM absorbed above the recommended dose, could cause severe health hazards [2, 3]. Heavy metals could be bio-accumulated through different trophic levels and unlike organic toxicants considered non-biodegradable $[4,5]$.

Over the last two decades there was an extensive use of $\mathrm{Cd}$ worldwide for production of batteries compared with its use for other applications. There were several international agreements and legislation to regulate and monitor the emission of $\mathrm{Cd}$ to the environment consequently; minimizing human and environmental threat of $\mathrm{Cd}$ which could cause failure of kidney in all mammals [6, 7]. Also, Cd has particular environmental interest as one of the toxic heavy metals, because it could be accumulates in soils via agricultural usage of fertilizers, sewage residues, disposal of $\mathrm{Cd}$ polluted wastes (industrial as well as municipal). Cadmium is an outstanding human cancer-causing agent and may cause hypertension, bone injuries and lung deficiency $[8,9]$.

Adsorption among the available remedial technologies is the most popular because of its simplicity and low cost. Different natural (e.g. metal oxides, bentonites, natural zeolites) and synthetic (resins, modified zeolites, synthetic hydroxides /oxides/hydroxides, metal phosphates and silicates) materials have been tested in adsorption process for removal of heavy metal from wastewater with various efficiencies [10, 16]. In addition, significant research work has been done on different waste materials to improve and investigate proper sorbents for water and wastewater treatment, blast furnace slug [17, 18], biomass [19, 20], fly ash [21], and bagasse fly ash $[22,23]$, among other have been investigated as sorbents for removal of heavy metal with various levels of achievement.

Nano-metal oxides are a highly valuable material with various applications in catalysts [24], gas sensors [25], optical, electrical and mechanical devices (Yi et al. 2011), cosmetics

*Corresponding author e-mail: ksayed6631@gmail.com

DOI : 10.21608/ejchem.2017.1289.1076

C2017 National Information and Documentation Center (NIDOC) 
and sunscreens [26]. Nano-metal oxides such as hydrous manganese oxides, iron, aluminum, titanium oxides and zinc oxide are extensively used for removal of heavy metal ions from water and wastewater. These nano-metal oxides can be manufactured by different techniques such as microwave-assisted route [27], chemical vapor deposition (CVD), different hydrothermal techniques and sol-gel method [28].

The main objectives of this study are the synthesis a nominal nano-calcium silicate (wollastonite) ceramic doped with $\mathrm{CuO}$ as metal oxide using a very simple technique. As well as, investigate the adsorption capacity of the produced nano-composite as an adsorbent material to remove of $\mathrm{Cd}$ ions from water samples.

\section{Materials and Methods}

\section{Materials}

Nominal nano-calcium silicate ceramic (wollastonite) was prepared from calcium carbonate (El-Gomhorya Company for Chemicals, Egypt 99\%), silicon hydroxide gel (Fluka) and copper carbonate $\left(\mathrm{CuCO}_{3}\right)$. The source of $\mathrm{Cd}(\mathrm{II})$ used in the adsorption studies was high purity cadmium chloride hexahydrate $\left(\mathrm{CdCl}_{2} \cdot 6 \mathrm{H}_{2} \mathrm{O}\right)$, (Chem-Supply-Merck).

\section{Synthesis of Nominal nano-calcium silicate ceramic}

Nominal calcium silicate ceramic (wollastonite) was prepared from pure calcium carbonate, silicon hydroxide (silica gel) and copper carbonate $\left(\mathrm{CuCO}_{3}\right)$, was used as precursors for $\mathrm{CuO}$ was doped $(0.0-7 \mathrm{~g} / 100$ g $\mathrm{CaSiO}_{3}$ powder). $\mathrm{CaCO}_{3}$ was dissolved in stochimetric amount of nitric acid $\left(\mathrm{HNO}_{3}\right)$. The freshly prepared calcium nitrate $\left[\mathrm{Ca}\left(\mathrm{NO}_{3}\right)_{2}\right]$ was dissolved in appropriate amount of distilled water gently with slow stirring. The silicon hydroxide gel was added slowly to the calcium nitrate under vigorous stirring for $2 \mathrm{~h}$ to ensure good mixing. The $\mathrm{CuO}$ dopant , freshly prepared from $\mathrm{CuCO}_{3}$ with distilled water to gave $\mathrm{Cu}(\mathrm{OH})_{2}$ was added under continues vigorous stirring for $1 \mathrm{hr}$. The homogenous composite was dried at $100^{\circ} \mathrm{C}$ overnight followed by calcined at $550^{\circ} \mathrm{C} / 2 \mathrm{~h}$. The following equations explain the steps of produce $\mathrm{CaSiO}_{3}$ with and without $\mathrm{CuO}$ dopant :

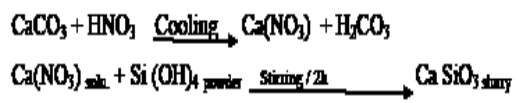

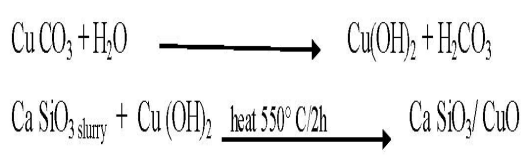

X-ray investigations of the $\mathrm{CaSiO}_{3}$ with $/ \mathrm{CuO}$ calcined at $550^{\circ} \mathrm{C}$ in air for $2 \mathrm{~h}$ was conducted using XRD (BRUKER, D8 ADVANCED $\mathrm{Cu}$ target, Germany). XRD was carried out in the range from 20 to $602 \theta^{\circ}$. The morphology of the sample was checked via scanning electron microscopy (SEM) coupled with energy-dispersive spectroscopy EDX, (SEM Model Quanta FEG 250).

\section{Removal of the metal ions using the nano-ceramic sorbent}

A batch sorption method was used to study the efficiency of the nano-ceramic for the removal of $\mathrm{Cd}$ ions. The influences of initial metal ion concentration, adsorbent dose, contact time and $\mathrm{pH}$ of solution on the sorption of $\mathrm{Cd}$ ions were examined. A Jar test procedure was used for ensuring homogeneity of the metal ions salts in solutions. The metal ions were estimated in the samples after filtration with filter papers Whatman ${ }^{\circledR}$ (No. 41). Control samples without adsorbent were used for comparison between sorption and precipitation of metal ions. All experiments were repeated three times, the percentage of metal ions removal by the nanoceramic was measured for all samples using inductive coupled plasma optical emission spectrometry (Agilent ICP-OES 5100) according to standard methods for the examination of water and wastewater [APHA, 2012].

\section{Results and Discussion}

Characterization of nano-ceramic sorbent

The $\mathrm{X}$ ray diffraction pattern of calcined $\mathrm{CaSiO}_{3} / \mathrm{CuO}$ powder was shown in Fig. 1. The identified phases were wollastonite $\left(\mathrm{CaSiO}_{3}\right.$, ICDD, 01-076-0925) and for tenorite $(\mathrm{CuO}$, ICDD, 00-005-0661).

The SEM micrograph of the calcined $\mathrm{CaSiO}_{3} /$ $\mathrm{CuO}$ powder before soaking in waste water was shown in Fig. 2. The photograph show cluster of nano-particles within 29-45 nm nano-meter, however some connected barrier of nano-particles which make boxes or pores were clearly visible in the all sample field (Fig.2). Micrograph of the sample, illustrate some tiny particles as well 
as particles of a somewhat larger size indicating some of crystallinity. Figure 2 shows that, the particles are near uniform spherical, the irregular surface of the particles increases the surface area and the particle size can be estimated in the range of 29-45 $\mathrm{nm}$. The resulting microstructure and the pore size distribution of the obtained ceramic

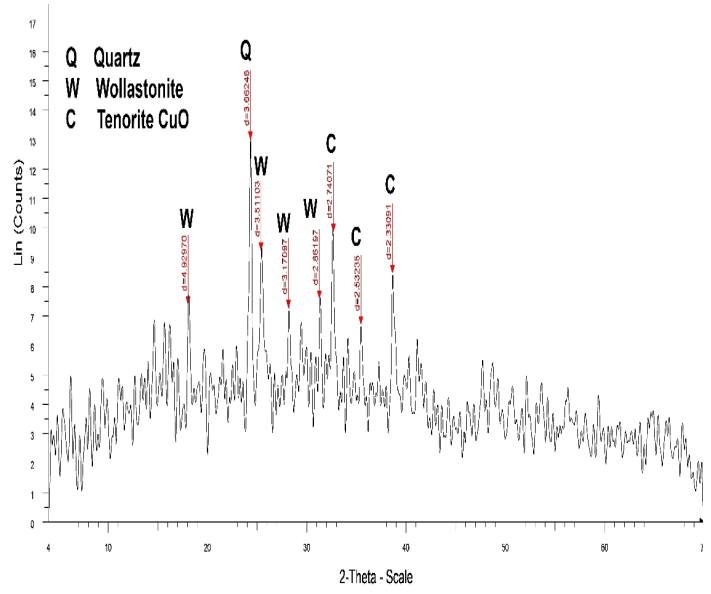

Fig. 1. $\mathrm{X}$ ray diffraction patterns of $\mathrm{CuO}$ - doped wollastonite treated at $550^{\circ} \mathrm{C} / 2 \mathrm{hr}$.

are particularly important for potential adsorption applications.

The $\mathrm{pH}$ has significant effect on adsorption, as it affects the surface charge of adsorbent and also chemical speciation of the adsorbate. Adsorption of $\mathrm{Cd}$ ions was studied at different $\mathrm{pH}$ ranging from 3 upto 9 where, $\mathrm{Cd}^{2+}, \mathrm{Cd}(\mathrm{OH}), \mathrm{Cd}(\mathrm{OH})_{2}$, and $\mathrm{Cd}(\mathrm{OH})_{2(\mathrm{~S})}$ are the forms of cadmium present in de-ionized water. In these experiments adsorbate concentration was $25 \mathrm{mg} / \mathrm{L}$, ceramic mass was $0.75 \mathrm{~g}$ at contact time varying from 0 to $60 \mathrm{~min}$.

Figure 3 shows the effect of $\mathrm{pH}$ on adsorption

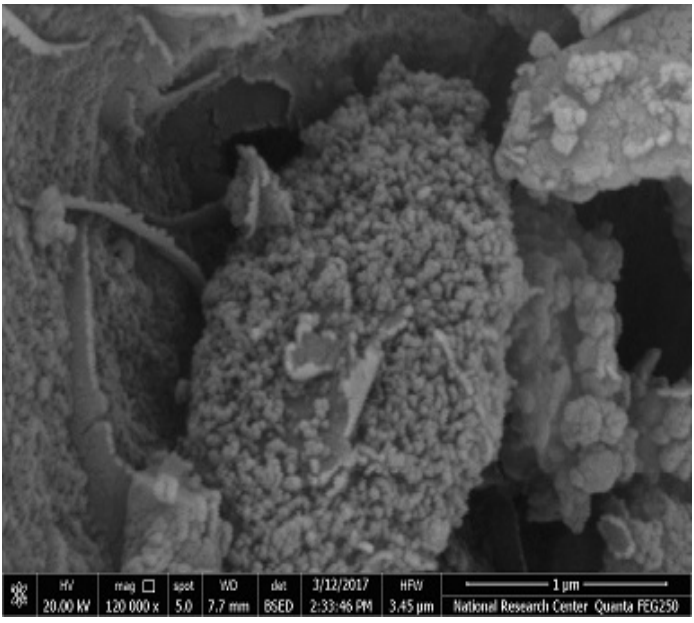

Fig. 2. SEM of the Nano-ceramic before Cadmium adsorption.

process (initial $\mathrm{Cd}$ concentration was $25 \mathrm{mg} / \mathrm{l}$ ). It can be seen that, adsorption increases with increasing the $\mathrm{pH}$ of the solution. The removal efficiency increased from $43.2 \%$ at $\mathrm{pH} 3$ to 98.88 $\%$ at $\mathrm{pH}$ 9. Where, at lower $\mathrm{pH}$ values $\mathrm{H}^{+}$ions compete with $\mathrm{Cd}(\mathrm{II})$ ions for binding sites on the absorbent surface. However, as the $\mathrm{pH}$ increases there is a reduction in competition between $\mathrm{H}^{+}, \mathrm{Cd}^{2+}$ and $\mathrm{Cd}(\mathrm{OH})^{+}$ions and as a result, metal uptake by the absorbent increases. The experimental results indicate that, $\mathrm{Cd}(\mathrm{II})$ removal was predominantly controlled by adsorption upto a $\mathrm{pH}$ 8. It was showed that [29], the $\mathrm{Cd}$ (II) ion predominates at $\mathrm{pH}$ below 7 and it begins to precipitate out as $\mathrm{Cd}(\mathrm{OH})_{2}$ at $\mathrm{pH}$ values just above 9. Based on the results, further experiments were conducted at $\mathrm{pH} 9$.

\section{Effect of contact time}

Adsorption of $\mathrm{Cd}$ ions was studied at different contact time ranging from 0 to $120 \mathrm{~min}$. with

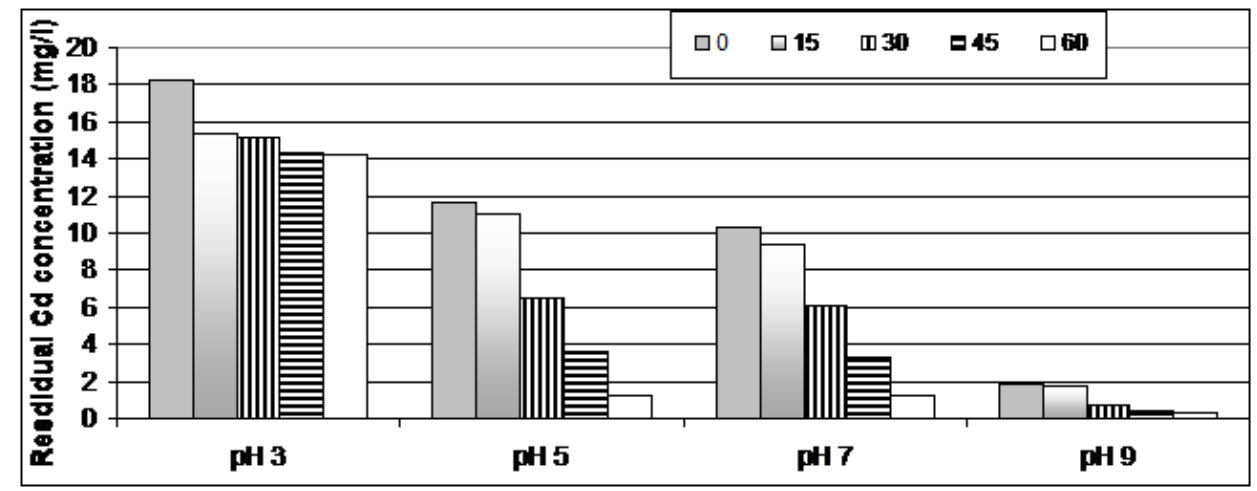

Fig. 3. Effect of $\mathrm{pH}$ value on the removal efficiency of $\mathrm{Cd}$ ions by using the nano-ceramic (initial Cd concentration was $25 \mathrm{mg} / \mathrm{l})$. 
$25 \mathrm{mg} / \mathrm{L}$ of adsorbate concentration, the nanoceramic mass was $0.75 \mathrm{~g}$ and $\mathrm{pH} 9$. Figure 4 shows the influence of contact time on the efficiency of the nano-ceramic for the removal of Cd(II) ions. It can be noted that, the removal efficiency increased from $92.4 \%$ to $98.88 \%$ and almost

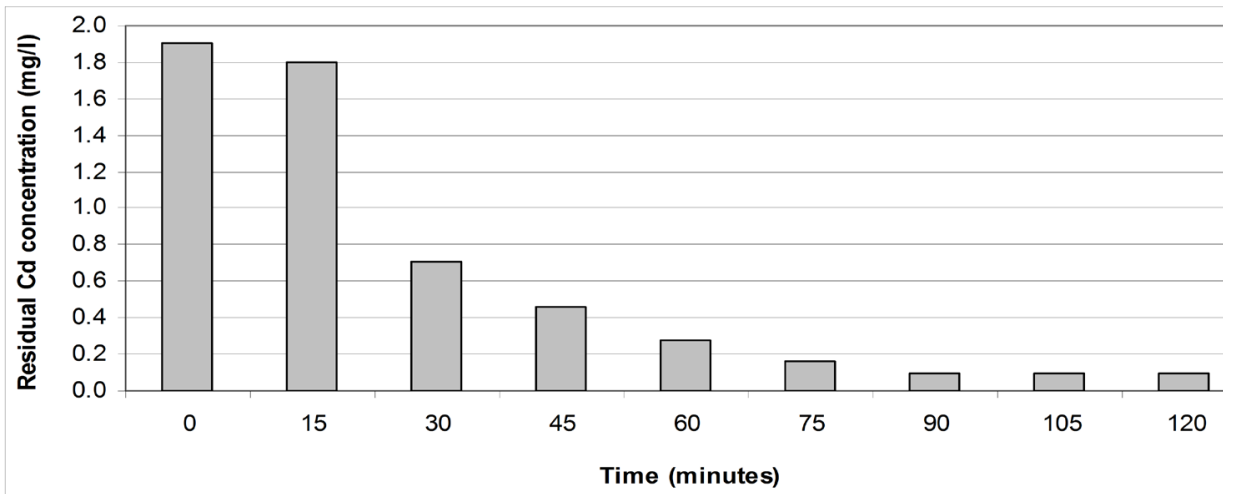

Fig. 4. Effect of contact time on the removal efficiency of Cd ions by using the nano-ceramic at pH: 9 and T: 298 (initial Cd concentration was $25 \mathrm{mg} / \mathrm{l}$ ).

remain constant from 60 until $120 \mathrm{~min}$. Therefore, the equilibrium adsorption time is $60 \mathrm{~min}$.

\section{Effect of adsorbent dosage on adsorption}

The effect of adsorbent dose was studied using $25 \mathrm{mg} / \mathrm{L}$ of adsorbate concentration, at $\mathrm{pH} 9$ with nano-ceramic mass varied from 0.25 to $1.0 \mathrm{~g} / \mathrm{L}$ with $0.25 \mathrm{mg} / \mathrm{l}$ intervals, at contact time ranging from 0 to $60 \mathrm{~min}$.

The general trend indicates that, 0.25 to 0.75 $\mathrm{g} / \mathrm{L}$ of sorbent dose uptake huge percent of $\mathrm{Cd}(\mathrm{II})$ (Fig. 5) where, it can be observed that the removal efficiency increased from $96.04-98.88 \%$ and nearly remain constant from $0.75-1.0 \mathrm{~g} / \mathrm{L}$. The reason for the increasing of removal efficiency could be attributed to the increasing of adsorbent dose that means increase of the total available surface area of the adsorbent particles. Beyond $0.75 \mathrm{~g} / \mathrm{L}$, the removal remained almost unaffected by the adsorbent dosage so, at $0.75 \mathrm{~g} / \mathrm{L}$, the adsorbent surface becomes saturated with $\mathrm{Cd}(\mathrm{II})$.

\section{The SEM of Cd on the nano-ceramic sorbent}

The SEM micrograph of the Cd loaded on nano-calcium silicate (wollastonite) doped with $\mathrm{CuO}$ is shown in Fig. 6. The photos show light coated nano-particles of Cd-metal on the surface of ceramic. It could be noted from Fig.6, that the surface morphology and porosity of the nanoceramic (wollastonite) doped with $\mathrm{CuO}$ were drastically changed after loading of cadmium as compared with the surface shape of the blank adsorbents. The EDS microanalysis indicates the

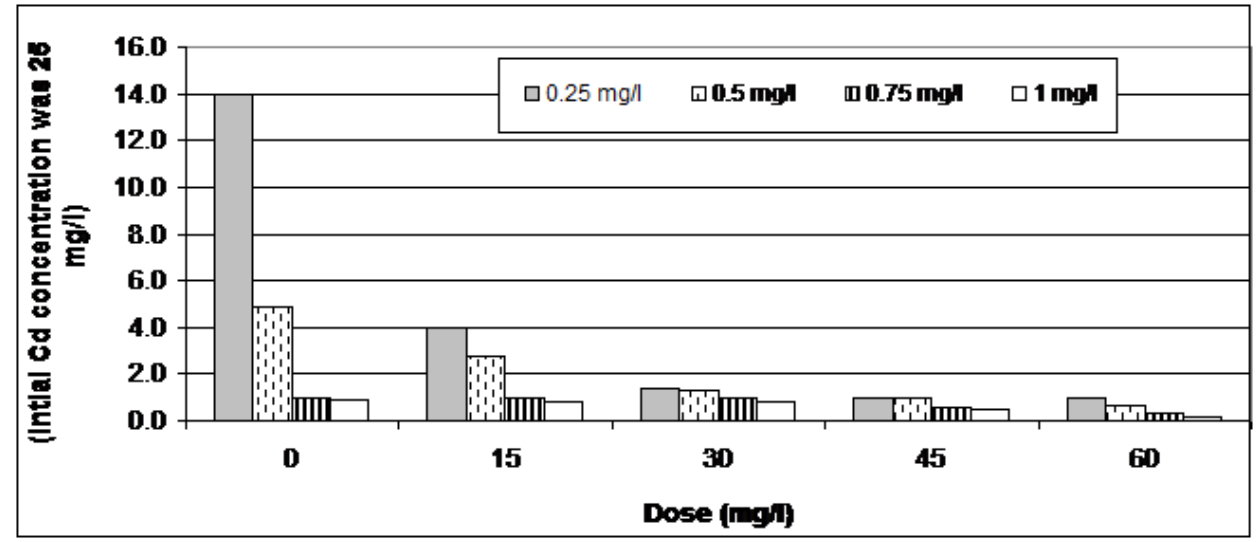

Fig. 5. Effect of adsorbent dosage of the nano-ceramic on the removal efficiency of Cd ions at pH: 9 and T: 298 (intial Cd concentration was $27.4 \mathrm{mg} / \mathrm{l}$ ).

Egypt. J. Chem. 60, No.5 (2017) 


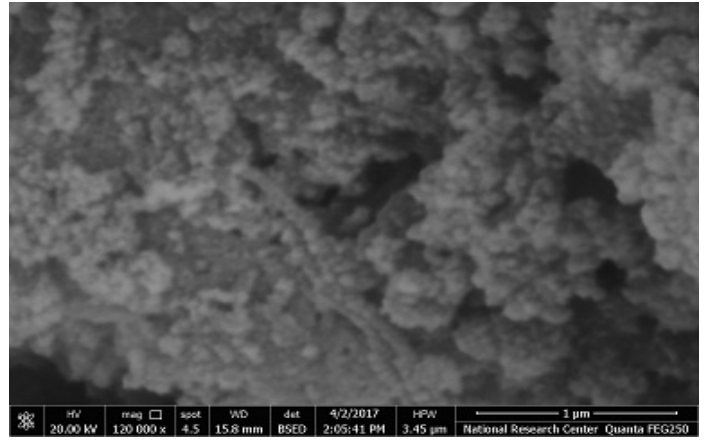

Fig. 6. SEM of the nano-ceramic sample after cadmium adsorption. presence of cadmium cations after adsorption onto surface of nano-ceramic doped with $\mathrm{CuO}$ (Fig.7).

The aforementioned results were in agreement with previous work where, the synthesized nano-structured calcium silicates showed that the synthesized material based on an amorphous materials without a defined structure. In our work the particle size were ranged from 29-45 nano-meter synthesized using commercially inorganic materials, while for the previous work the mean particle size

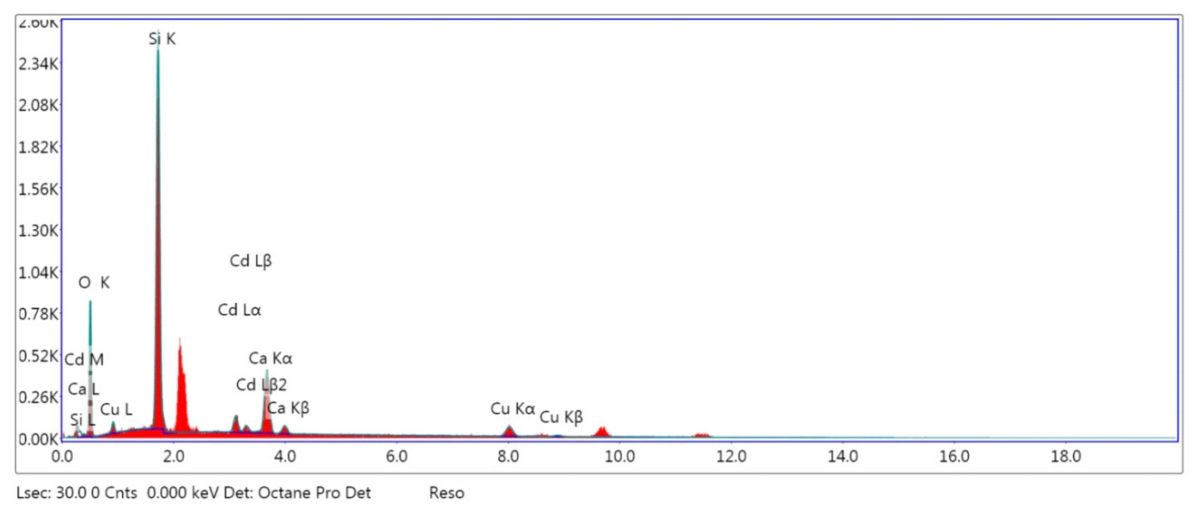

Fig.7. Energy dispersive spectrum (EDS) of the Cd-loaded nano-Calcium Silicate doped with CuO.

averaging was 0.5 to $1.0 \mu \mathrm{m}$ with particles forming larger agglomerates.

\section{Conclusions}

- Nano-Calcium Silicate doped with nanocopper is found to beneficial for removing of heavy metal such as $\mathrm{Cd}$ from an aqueous solution. The studied material was synthesized using very simple technique (coprecipitation method) from low coast starting chemicals. The prepared ceramic doped with $\mathrm{CuO}$ was investigated using different tools.

- Higher uptakes (98.88\% of $\mathrm{Cd}(\mathrm{II}))$ from aqueous solution is possible using wollastonite as an adsorbent provided the initial concentration of the $\mathrm{Cd}(\mathrm{II})$ in the wastewater is around $25 \mathrm{mg} / \mathrm{l}$. This material could be used for industrial wastewater treatment.

- The $\mathrm{pH}$ has been found to be a master variable controlling the adsorption of $\mathrm{Cd}(\mathrm{II})$ by the oxides present in wollastonite. The adsorption is maximum around $\mathrm{pH} 9.0$ and it has been concluded that surface complexation involving $\mathrm{H}^{+}$exchange and chemical precipitation contribute towards maximum uptake.

\section{References}

1. American Public Health Association, Standard methods for the examination of water and wastewater, 22nd ed., Washington, DC: APHA, (2012).

2. Antonio, J.R.C., Samuel, P.D.M., Joao, M.S., Josue, M.F., Gilberto, D.S. and Alcineia, C.O., Nanosized aluminum derived oxides catalysts prepared with different methods for styrene production, Chemical Engineering Journal 209(1), 345-355(2012).

3. Ayangbenro, A.S. and Babalola, O.O., A new strategy for heavy metal polluted environments: a review of microbial biosorbents, International Journal of Environmental Research and Public Health 14(94), (2017); doi:10.3390/ ijerph14010094

4. Chubar N., Carvalho J.R. and Correia M.J.N., Cork Biomass as Biosorbent for $\mathrm{Cu}(\mathrm{II}), \mathrm{Zn}(\mathrm{II})$ and

Egypt. J. Chem. 60, No.5 (2017) 
Ni(II), Colloids Surfaces A: Physicochemical and Engineering Aspects, 230(1), 57-65, (2003).

5. Ciccu R., Ghiani M., Serci A., Fadda S., Peretti R. and Zucca A., heavy metal immobilization in the mining-contaminated soils using various Industrial Wastes, Minerals Engineering, 16(3), 187-192(2003).

6. Dimitrova, S.V. and Mehandriev, D.R., Lead removal from aqueous solutions by granulated blast-furnace slag, Water Research, 32(11), 32893292 (1998).

7. Epifani, M., Comini, E., Diaz, R., Arbiol, J., Siciliano, P., Sberveglieri, G. and Morante, J.R., Oxide nanopowders from the low-temperature processing of metal oxide sols and their application as gas-sensing materials. Sens Actuators B, Chem 118(1-2), 105-109(2006).

8. Farid, G., Sarwar, N., Saifullah and Ahmad, A., Abdul Ghafoor and Rehman M., Heavy metals $(\mathrm{Cd}, \mathrm{Ni}$ and $\mathrm{Pb})$ contamination of soils, plants and waters in madina town of faisalabad metropolitan and preparation of gis based maps, Advances in Crop Science and Technology, 4:199(2015),doi:10.4172/2329-8863.1000199.

9. Garg, U., Kaur, M.P., Jawa, G.K., Sud, D. and Garg, V.K., Removal of cadmium(II) from aqueous solutions by adsorption on agricultural waste biomass, Journal of Hazardous Materials., 154, 1149, (2008).

10. Gundogan, R., Acemioglu, B. and Alma, M.H., Copper(II) Adsorption from Aqueous Solution by Herbaceous Peat, Journal of Colloid and Interface Science., 269(2), 303(2004).

11. Hegazi, H.A., Removal of heavy metals from wastewater using agricultural and industrial wastes as adsorbents, Housing and Building National Research Center (HBRC) Journal, 9, 276-282(2013).

12. Ho, Y.S. and Mckay, G., The sorption of Llead(II) ions on peat, water research, 33, 578(1999).

13. Kaji, M., Role of experts and public participation in pollution control: the case of Itai-itai disease in Japan, Ethics in Science and Environmental Politics, 12, 99-111(2012).

14. Lagashetty, A.K., Havanoor, V.A., Basavaraja, S., Balaji, S.D. and Venkataraman, A., Microwaveassisted route for synthesis of nanosized metal oxides. Science and Technology of Advanced
Materials, 8(6), 484-493, (2007)

15. Lu, B., Chen, S. and Kawamoto, K., Direct hydrothermal synthesis of nanosized mesoporous ramsdellite manganese oxide with high surface area, Materials Research Bulletin 47(11), 36193624 (2012).

16. Mahdavi, S., Jalali, M. and Afkhami, A., Heavy metal removal from aqueous solutions using $\mathrm{TiO}_{2}, \mathrm{MgO}$, and $\mathrm{Al}_{2} \mathrm{O}_{3}$ nanoparticles, Chemical Engineering Communications 200(3),448-470, (2013).

17. Mckay, G. and Ho, Y.S., Pseudo-secondorder model for sorption processes. Process Biochemesrty, 34, 451-465(1999)

18. Mobasherpour, I., Salahi, E. and Pazouki, M., Removal of divalent cadmium cations by means of synthetic nano-crystallite hydroxyapatite, Desalination, 266, 142-148(2011).

19. Pagnanelli, F., Veglio, F. and Toro, L., Modelling of the Acid-Base Properties of Natural and Synthetic Adsorbent Materials Used for Heavy Metal Removal from Aqueous Solutions, Chemospere, 54(7), 905-915(2004).

20. Park, K.T., Gupta ,V.K., Mohan, D. and Sharma, S., Removal of chromium(VI) from electroplating industry wastewater using bagasse fly ash — a sugar industry waste material, The Environmentalist, 19(2), 129-136(1999).

21. Ramos, R.L., Rangel-Mendez, J.R., MendozaBarron, J., Fuentes-Rubio, L. and GuerreroCoronado, R.M., Adsorption of cadmium (II) from aqueous solution onto activated carbon. Water Science and Technology, 35, 205-211(1997).

22. Reed, B.E. and Matsumoto, M. R., Modelling of cadmium adsorption by activated carbon using langmuir and freundlich expressions, Separation Science and Technology, 28, 2179(1993).

23. Sekhar, K.C., Kamala, C.T., Chary, N.S., Sastry A.R.K., Nageswara Rao, T. and Vairamani, M., Removal of lead from aqueous solutions using an immobilized biomaterial derived from a plant biomass, Journal of Hazardous Materials, 108(12), 111-117(2004).

24. Shin, E.W., Karthikeyan, K.G. and Tshabalala, M.A., Adsorption mechanism of cadmium on juniper bark and wood, Bioresource Technology, 98(3), 588-594 (2007), doi:10.1016/j.biortech. 2006.02.024 
25. Tomoyuki, K. and Asa, K., Ultraviolet-screening zinc oxide excellent in transparency and composition containing the same, US patent No 6 , 171, 580(2001).

26. Tripathi, A. and Ranjan, M.R., Heavy Metal Removal from Wastewater Using Low Cost Adsorbents, Journal of Bioremediation and Biodegradation , 6, 315(2015), doi:10.4172/21556199.1000315

27. Xu, Y. and Axe, L., Synthesis and Characterization of iron oxide-coated silica and its effect on metal adsorption, Journal of Colloid and Interface Science, 282(1), 11-19 (2005).

28. Yi, Y., Yang, Z. and Zhang, S., Ecological risk assessment of heavy metals in sediment and human health risk assessment of heavy metals in fishes in the middle and lower reaches of the Yangtze River basin, Environmental Pollution, 159, 2575-2585, (2011).

29. Zhu, R., Yu ,R., Yao, J., Mao, D., Xing, C. and Wang, D., Removal of $\mathrm{Cd}^{2+}$ from aqueous solutions by hydroxyapatite, Catalysis Today, 139, 94-99(2008).

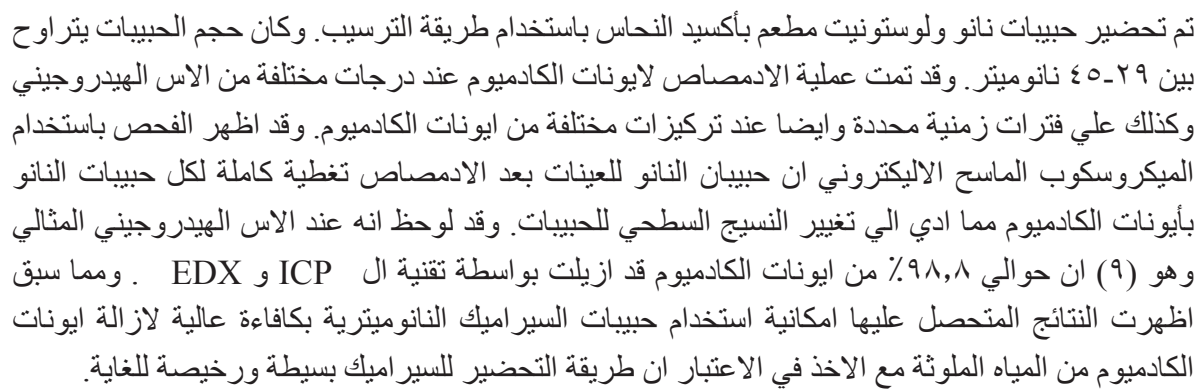

